\title{
Ultrafiltration performance of PVDF, PES, and cellulose membranes for the treatment of coconut water (Cocos nucifera $L$.)
} Isabel Cristina do Nascimento DEBIEN ${ }^{1 *}$, Maria Thereza de Moraes Santos GOMES ${ }^{1}$, Ricardo Schmitz ONGARATTO ${ }^{1}$, Luiz Antonio VIOTTO ${ }^{1}$

\begin{abstract}
Ultrafiltration (UF) inhibits the enzymatic activity which is responsible for color changes of coconut water without the need for heat treatment. In the present study, UF performance in terms of the permeate flux and enzymatic retention of the coconut water was evaluated at laboratory unit (LU) and pilot unit (PU). The membranes studied were polyethersulfone $150 \mathrm{kDa}$ (UP150), polyvinylidene fluoride $150 \mathrm{kDa}$ (UV150) and cellulose $30 \mathrm{kDa}$ (UC030). The UP150 membrane showed the best permeate flux. The UC030 membrane showed the lowest flux, but it resulted in 100\% enzymatic retention, while the other membranes showed enzymatic retentions between 71 and 85\%. The application of the UC030 in the pilot unit (PU) resulted in a flux value higher than that obtained in the LU due to the tangential velocity effect. The UC030 membrane has proved adequate for industrial applications.
\end{abstract}

Keywords: coconut water; polyphenol oxidase; peroxidase.

\section{Introduction}

Coconut water is a natural isotonic, low-calorie, nutritious beverage known worldwide and greatly appreciated in Brazil. In addition to its various traditional uses, this refreshing drink has recently been described as a "sport beverage" and has drawn attention of manufacturers to produce it as a natural functional drink (PRADES et al., 2012). Its consumption, whether in natura or processed, has increased in recent years due to its health benefits. The processing methods employed are mainly aimed at inhibiting the action of enzymes, polyphenol oxidase (PPO), and peroxidase (POD), which are responsible for coconut water color change to pink and ensuring its microbiological stability after the fruit is cut, while retaining its original sensory characteristics as much as possible (MAGALHÃES et al., 2005).

In its simplest form, membrane separation consists of pumping the feed material under pressure onto a membrane surface. There are two configurations: the static method (conventional filtration), also known as perpendicular filtration; and tangential filtration, in which the fluid flows parallel to the membrane surface (CHERYAN, 1998).

Processes with membranes have been consolidated in various areas of food production and have been replacing conventional fining in the clarification of fruit juices (ALPER; ONSEKIZOGLU; ACAR, 2011). They are alternatives to conventional thermal processes since it is a non-thermal separation with no phase changes or addition of chemical agents; in addition, membrane is a selectively permeable barrier that separates one or more solutes from the fluid, including microorganisms. (ALMANDOZ et al., 2010; GIRARD; FUKUMOTO, 2000). Magalhães et al. (2005) reported the applications of MF and UF in the clarification of coconut water. The ultrafiltrated coconut water showed reasonably good shelf life. Reddy, Das and Das (2005) reported a twostage filtration process for coconut water. Jayanti et al. (2010) investigated UF of coconut water in a continuous stirred cell varying transmembrane pressure and stirring rate; they proposed a simple first-order kinetic model for quantification of flux decline during UF. These studies on the use of MF or UF to stabilize coconut water were cited in a review article by Prades et al. (2012).

Coconut water is a tropical product that has been scarcely studied concerning membrane applications for the production of a sterile and natural product with high consumer acceptance. The applications of many types of membranes that result in high permeate flux and polyphenol oxidase and peroxidase enzyme retention are yet to be explored. Therefore, it is necessary to study different materials and pore sizes to identify the best membrane to produce permeate that can be bottled immediately after collection. The objective of this study was to evaluate the performance of polyethersulfone $150 \mathrm{kDa}$ (UP150), polyvinylidene fluoride $150 \mathrm{kDa}$ (UV150), and cellulose 30 $\mathrm{kDa}$ (UC030) membranes in the treatment of coconut water. The permeate flux and enzymatic retention were evaluated for coconut water processed at a laboratory unit (LU) and pilot unit (PU) in UF processes. The mathematical model for predicting permeate flux was developed based on the surface renewal theory. The main purpose of this study was to evaluate different membrane materials for coconut water processing in UF processes. Furthermore, this study aimed to obtain high permeate flux with high enzymatic retention that can make industrial application feasible since high permeate flux is

Received 2/25/2013

Accepted 8/20/2013 (006019)

LAMEFI/DEA, School of Food Engineering - FEA, University of Campinas - UNICAMP, Cidade Universitária “Zeferino Vaz", Rua Monteiro Lobato, 80, CEP 13083-862,

Campinas, SP, Brazil, e-mail: isadebien@gmail.com

${ }^{*}$ Corresponding author 
associated with high productivity and attractiveness because enzymatic retention is a quality parameter for coconut water.

\section{Materials and methods}

\subsection{Raw material}

The coconut water used in the experiments was extracted from seven month old green dwarf coconuts. Three batches of 40 coconuts were purchased from the Central Supply of Campinas (CEASA) in Campinas/SP/Brazil.

\subsection{Membranes}

Three following flat polymer membranes were used: UC030, UV150, and UP150 (Microdyn-Nadir, Germany). Table 1 shows the main characteristics of the tested membranes. The dry flat membranes were soaked in distilled water for a period of at least 24 hours prior to use to wet the pores (KIM; LIU; EL-DIN, 2011; BRUGGEN et al., 2004).

\subsection{Experimental procedure}

The fruits were cleaned and sanitized in three steps: firstly, by washing with potable water to remove plant debris and dirt resulting from transportation; secondly, by immersion in chlorine solution $\left(200 \mathrm{mg} \cdot \mathrm{L}^{-1}\right)$ for 10 minutes to remove contaminants from the shell; and lastly, by immersion in a sodium hypochlorite solution $\left(5 \mathrm{mg} \cdot \mathrm{L}^{-1}\right)$ to remove any remaining sanitizer.

The coconut water was extracted manually with a device made from a stainless steel tube and polystyrene handle. It was filtered to remove coarse solids through a stainless steel sieve (mesh size 20 and $850 \mu \mathrm{m}$ opening). In order to inhibit enzymatic activity before and during the process, $200 \mathrm{mg}$ of ascorbic acid per liter of coconut water in natura was added immediately after extraction (CAMPOS et al., 1996).

\section{Laboratory Unit (LU)}

The LU is ideal for the evaluation of operating conditions such as membrane type, temperature, and pressure due to its operation capacity. The experiments conducted at the LU were performed in a stirred cell, as illustrated in Figure 1, with a capacity of $800 \mathrm{~mL}$ and a permeation area of $0.01 \mathrm{~m}^{2}$ at $25^{\circ} \mathrm{C}$. It was subjected to pressures of $0.5,1.5$, and 2.0 bar for the UV150 and UP150 membranes and 2.0, 4.0 and 6.0 bar for the UC030 membrane. A magnetic stirrer (300 rpm) was used, starting with $400 \mathrm{~mL}$ of feed at $25^{\circ} \mathrm{C}$ (in natura coconut water with added ascorbic acid) that was concentrated until a volume reduction factor $(\mathrm{VRF})=2$ was achieved. The temperature was kept at $25{ }^{\circ} \mathrm{C}$ and controlled using a temperature circulating water bath. The runs were carried out in duplicates, and for each run, a new membrane was used. After each experiment, the unit was washed with commercial detergent and rinsed with distilled water.

\section{Pilot Unit (PU)}

The operating conditions used were similar to those of industrial ultrafiltration applications. The PU experiments were conducted at $25^{\circ} \mathrm{C}$ in a pilot unit (PU), illustrated in Figure 2, until reaching a VRF of 2 . Each experiment was conducted with a new membrane. It was used $20 \mathrm{~L}$ of feed solution (in natura coconut water with ascorbic acid) at a flow rate of $1.7 \mathrm{~m}^{3} \cdot \mathrm{h}^{-1}$, corresponding to a tangential speed of $6.8 \mathrm{~m} \cdot \mathrm{s}^{-1}$, and a transmembrane pressure of 2.0 bar (the transmembrane pressure is the mean of the entrance and exit membrane module pressures). The cross-section area of the membrane cell module was $35 \mathrm{~mm} \times 2 \mathrm{~mm}$ and a permeation area of $0.02 \mathrm{~m}^{2}$. A schematic diagram of the membrane cell used is shown in Figure 3.

Pressure was adjusted controlling the pump rotation by frequency inversion and adjusting the flow with the needle valve. Temperature was controlled by the passage of water through the water jacket at adequate temperature. The runs were carried out in duplicates. The pilot plant was cleaned using the CIP method (cleaning in place) with sodium hydroxide $1 \%$ and hydrochloric acid $1 \%$ solutions at $40{ }^{\circ} \mathrm{C}$. The solutions were separately circulated in pilot plant without the membrane for 20 minutes.

\subsection{Physicochemical analysis}

Some physicochemical analyses were performed in triplicate with coconut water before and after the ultrafiltration process to evaluate whether significant compositional changes occurred. The following analyses carried out: total solids, determined by drying in hot air oven according to the AOAC official method 920.15 (ASSOCIATION..., 1997); pH, measured using a potentiometer according AOAC official method 981.12 (ASSOCIATION..., 1997; titratable total acidity, determined by titration with $\mathrm{NaOH} 0.01 \mathrm{~N}$ and phenolphthalein as indicator according to the AOAC official method 942.15 (ASSOCIATION..., 1997); reducing and total sugars, determined by gravimetric copper reduction according to the AOAC official methods 952.35 (ASSOCIATION..., 1997) and 952.36 (ASSOCIATION..., 1997), respectively; color and turbidity, determined using a spectrophotometer and a $20 \mathrm{~mm}$ quartz cuvette, CIELAB color system, illuminant D65, $10^{\circ}$ observer angle, TTRAN-type calibration, and Haze measurements (tubidity) according to Hunterlab (1996). The results were analyzed by ANOVA followed by Tukeys test at a

Table 1. Characteristics of the UF membranes.

\begin{tabular}{cccccc}
\hline Membrane & Material & Cut-off $(\mathrm{kDa})$ & Pure water flux $\left(\mathrm{L} \cdot \mathrm{m}^{-2} \cdot \mathrm{h}^{-1}\right)$ & $\mathrm{pH}$ range & Max. temperature $\left({ }^{\circ} \mathrm{C}\right)$ \\
\hline UC030 & Regenerated cellulose (RC) & 30 & $>300^{\mathrm{a}}$ & $1-11$ & 55 \\
UV150 & Polyvinylidene fluoride (PVDF) & 200 & $>200^{\mathrm{b}}$ & $2-11$ & 95 \\
UP150 & Polyethersulfone (PES) & 150 & $>200^{\mathrm{b}}$ & $0-14$ & 95 \\
\hline
\end{tabular}

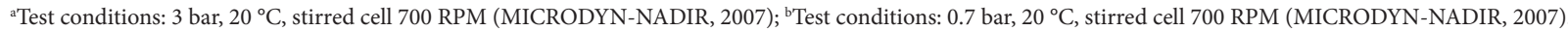




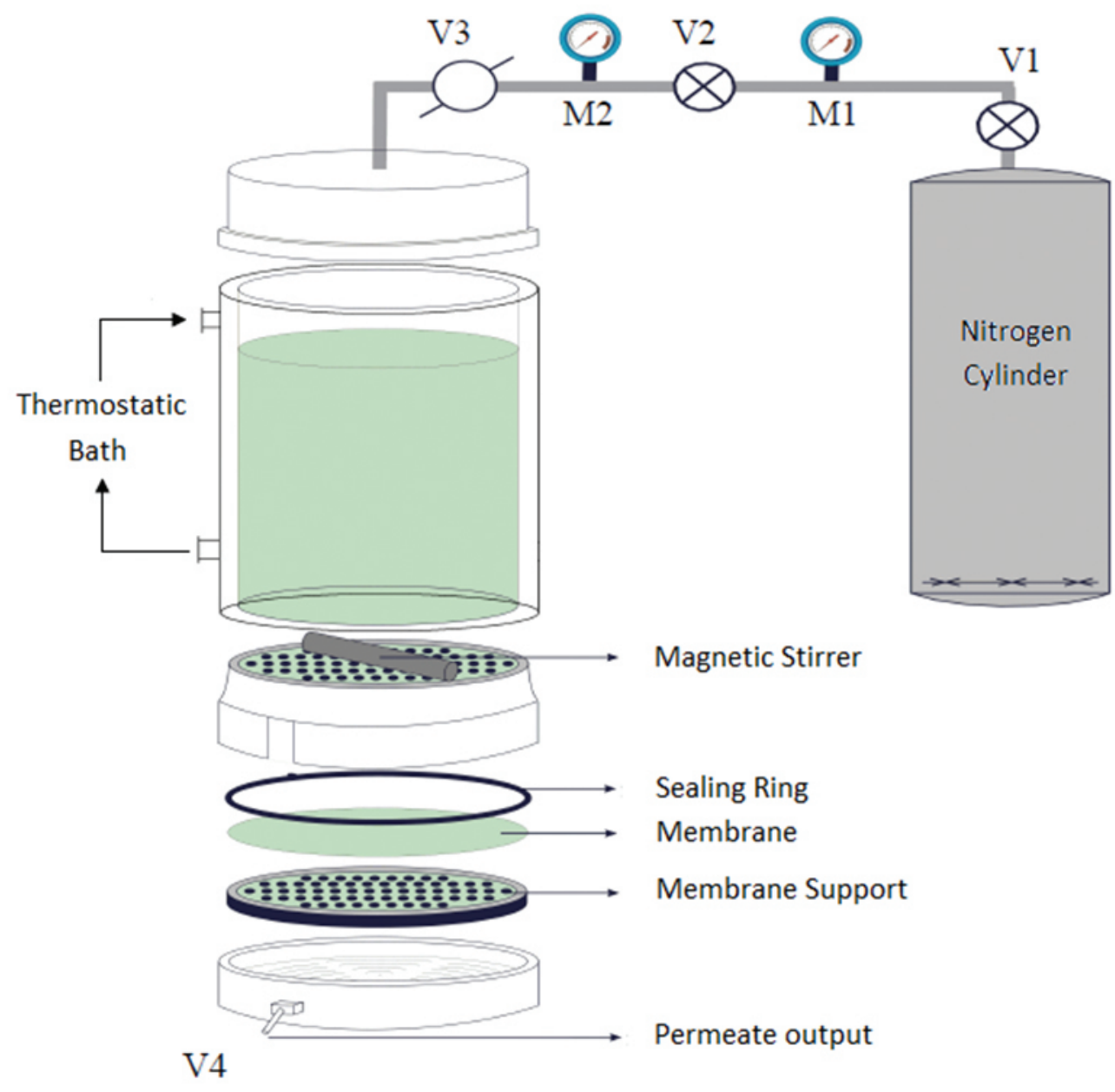

V1 - Valve open/close of the nitrogen cylinder

M1 - Manometer 1 (internal pressure in the nitrogen cylinder when V1 is open and V2 closed)

V2 - Regulation valve (regulates the pressure inside the unit)

M2 - Manometer 2 (pressure inside the unit)

V3 - Three-way valve

V4 - Permeate output valve

Figure 1. Schematic diagram of laboratory unit (LU).

confidence level of $95 \%$ to determine if there were significant differences using the $\mathrm{SAS}^{\circledR}$, version 9.0.0 software program.

\subsection{Permeate flux}

Permeate flux (J) is defined as the mass that passes through the membrane per unit of area and time and can be calculated according to Equation 1:

$J=\frac{m_{P}}{A_{P} \cdot t}$

where $m_{p}(k g)$ is the mass of permeate at time $t(\mathrm{~min})$ and $A_{p}$ is the permeation area $\left(\mathrm{m}^{2}\right)$.
There are different mathematical models available in the literature that have been used to describe the flux decline as a function of the process time. Most of them are semi empirical models. The LU and PU experimental flux data obtained were fitted to the mathematical model based on surface renewal theory (CONSTENLA; LOZANO, 1996), according to Equation 2:

$J=J_{F}+\left(J_{0}-J_{F}\right) e^{(-\lambda . t)}$

where $J_{0}$ and $J_{F}$ are the initial and final flux $\left(\mathrm{kg} \cdot \mathrm{h}^{-1} \cdot \mathrm{m}^{-2}\right)$, respectively, $\lambda\left(h^{-1}\right)$ is the decay rate of flux, and $t(h)$ is the time. 


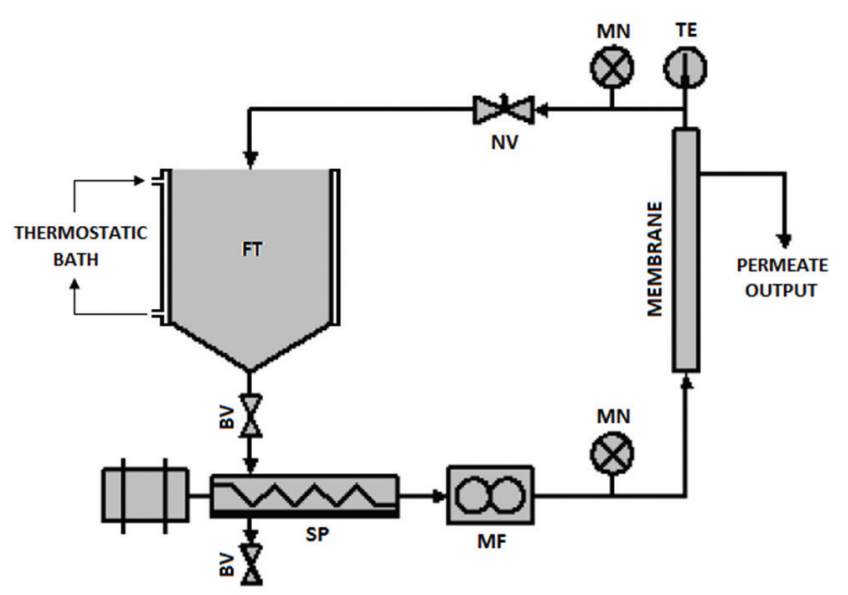

FT: Feed tank

BV: Butterfly valve

SP: Screw pump

MF: Magnetic flow meter

$\mathrm{MN}$ : Manometer

TE: Thermometer

NV: Needle valve

Figure 2. Schematic diagram of pilot unit (PU).

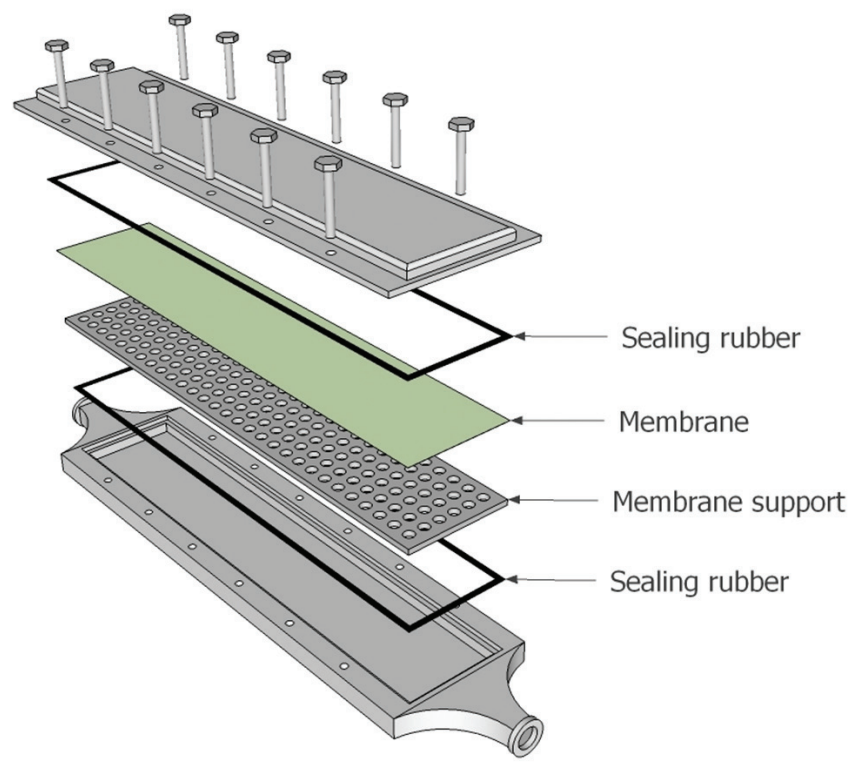

Figure 3. Schematic diagram of membrane cell used for PU tests.

\subsection{Enzyme activity}

Enzyme activity was determined based on the method of Campos et al. (1996). The PPO enzyme activity was determined using catechol as a phenolic substrate, the following solutions were poured into a glass cuvette at room temperature $\left(25^{\circ} \mathrm{C}\right)$ : $1.3 \mathrm{~mL}$ of $0.35 \mathrm{M}$ (pH 6.0) phosphate buffer, $0.7 \mathrm{~mL}$ of $0.2 \mathrm{M}$ catechol, and $2 \mathrm{~mL}$ of coconut water. The mixture was then stirred and homogenized, and absorbance was read in a spectrophotometer (BECMAN model DU ${ }^{\circledR}-70$, São Paulo, Brazil) at $425 \mathrm{~nm}$ at time zero and after 10 minutes of reaction The POD enzyme activity was determined using guaiacol as a phenolic substrate. An aliquot of $1.3 \mathrm{~mL}$ of $0.35 \mathrm{M} \mathrm{pH}$ (5.5) phosphate buffer was added in the glass cuvette, and subsequently it was kept in a water bath until its temperature of $35{ }^{\circ} \mathrm{C}$. Then, the following were added: $2.0 \mathrm{~mL}$ of coconut water, $0.2 \mathrm{~mL}$ of $0.1 \%$ hydrogen peroxide, and $0.5 \mathrm{~mL}$ of an alcoholic solution of $0.5 \%$ guaiacol solution in ethanol. The mixture was stirred and homogenized, and absorbance was immediately read in a spectrophotometer at $470 \mathrm{~nm}$, at time zero and after 10 minutes of reaction. For the POD enzyme activity assay, after the first reading at time zero, the cuvette was again placed in the water bath until the reaction time was completed, and the reading was then taken at 10 minutes. In all cases, the reactions to determine enzyme activity were carried out directly in the cuvette.

Enzyme activity is expressed as units $\cdot \mathrm{mL}^{-1}$. One unit corresponds to a change of 0.001 in absorbance per min per $\mathrm{mL}$ of sample. Equation 3 was used to calculate enzymatic activity:

$$
\operatorname{Activity}\left(U . m L^{-1}\right)=\frac{\left(A F_{\text {sample }}-A I_{\text {sample }}\right)-\left(A F_{\text {white }}-A I_{\text {white }}\right)}{0.001 \times t}
$$

where $\mathrm{AF}_{\text {sample }}$ is the final absorbance of the sample, $\mathrm{AI}_{\text {sample }}$ is the initial absorbance of the sample, $\mathrm{AF}_{\text {white }}$ is the final absorbance of the white, $\mathrm{AI}_{\text {white }}$ is the initial absorbance of the white, and $\mathrm{t}$ (min) is time.

Enzymatic retention was calculated according to Equation 4:

$$
R=100 \times\left(1-\frac{A_{p}}{A_{A}}\right)
$$

where $\mathrm{R}$ is the percentage of reduction, and $\mathrm{A}_{\mathrm{A}}$ and $\mathrm{A}_{\mathrm{p}}$ are the enzyme activities of the feed and permeate, respectively.

\section{Results and discussion}

\subsection{Physicochemical analysis}

Table 2 shows the results of the physicochemical analysis and compositions of the feed, retentate, and permeate of the experiments conducted at the LU at 2.0 bar. Pressure variation did not influence the results of the physicochemical analysis. The results showed no significant differences $(\mathrm{p} \leq 0.05)$ between the retentate and permeate in relation to the feed for total solids, $\mathrm{pH}$, titratable total acidity, and reducing and total sugars. As for the $\mathrm{pH}$, the feed values determined are consistent with those in the literature. Walter et al. (2009) found a pH value of 4.88 for coconut water aged for approximately 7 months. The values of acidity were slightly higher in the retentate for two membranes due to the concentration of non-dissociated acids and no change in the hydrogen ion concentration. The $\mathrm{pH}$ values were very similar to the fractions in both membranes.

With regard to the total and reducing sugar contents, the values found are higher in the retentate in some cases, showing a possible partial retention of these sugars due to the formation of a polarized layer, which acts as a second barrier thus increasing the resistance to the this component transport. 
Table 2. Physicochemical properties and composition of the feed, retentate and permeate.

\begin{tabular}{|c|c|c|c|c|c|c|}
\hline & & Total Solids (\%) & $\mathrm{pH}$ & Titratable Total Acidity* & Reducing Sugar (\%) & Total Sugar (\%) \\
\hline \multicolumn{2}{|l|}{ Feed } & $5.56 \pm 0.02^{\mathrm{ab}}$ & $4.77 \pm 0.02^{\mathrm{a}}$ & $89.30 \pm 0.20^{\mathrm{bc}}$ & $4.01 \pm 0.04^{\mathrm{b}}$ & $4.40 \pm 0.20^{\mathrm{bcd}}$ \\
\hline \multirow[t]{2}{*}{ UP150 } & $\mathbf{R}$ & $5.50 \pm 0.12^{\mathrm{ab}}$ & $4.77 \pm 0.01^{\mathrm{a}}$ & $88.18 \pm 1.65^{\mathrm{bdc}}$ & $4.44 \pm 0.02^{\mathrm{ab}}$ & $4.81 \pm 0.12^{\mathrm{abc}}$ \\
\hline & $\mathbf{P}$ & $5.29 \pm 0.24^{\mathrm{b}}$ & $4.74 \pm 0.02^{\mathrm{a}}$ & $86.06 \pm 0.08^{\mathrm{cd}}$ & $4.23 \pm 0.14^{\mathrm{ab}}$ & $4.56 \pm 0.07^{\mathrm{abcd}}$ \\
\hline \multirow[t]{2}{*}{ UV150 } & $\mathbf{R}$ & $5.50 \pm 0.07^{\mathrm{ab}}$ & $4.75 \pm 0.07^{\mathrm{a}}$ & $88.97 \pm 2.51^{b c}$ & $4.28 \pm 0.09^{\mathrm{ab}}$ & $4.50 \pm 0.16^{\mathrm{bcd}}$ \\
\hline & $\mathbf{P}$ & $5.75 \pm 0.16^{\mathrm{a}}$ & $4.78 \pm 0.07^{\mathrm{a}}$ & $89.05 \pm 0.30^{\mathrm{bc}}$ & $4.01 \pm 0.08^{\mathrm{b}}$ & $4.13 \pm 0.12^{\mathrm{d}}$ \\
\hline \multirow[t]{3}{*}{ UC030 } & $\mathbf{R}$ & $5.39 \pm 0.25^{\mathrm{b}}$ & $4.72 \pm 0.02^{\mathrm{a}}$ & $89.30 \pm 1.13^{\mathrm{bc}}$ & $4.08 \pm 0.05^{\mathrm{ab}}$ & $4.22 \pm 0.15^{\mathrm{cd}}$ \\
\hline & $\mathbf{P}$ & $5.48 \pm 0.09^{\mathrm{ab}}$ & $4.72 \pm 0.01^{\mathrm{a}}$ & $88.34 \pm 1.77^{\mathrm{bc}}$ & $4.06 \pm 0.09^{\mathrm{ab}}$ & $4.60 \pm 0.18^{\mathrm{abcd}}$ \\
\hline & & $\mathbf{L}^{*}$ & $\mathbf{a}^{*}$ & $\mathbf{b}^{*}$ & Haze & SSR (\%) \\
\hline \multicolumn{2}{|l|}{ Feed } & $94.65 \pm 0.01^{\mathrm{a}}$ & $-0.31 \pm 0.01^{\mathrm{c}}$ & $2.34 \pm 0.01^{\mathrm{c}}$ & $23.64 \pm 0.02^{c}$ & - \\
\hline \multirow[t]{2}{*}{ UP150 } & $\mathbf{R}$ & $94.48 \pm 0.30^{\mathrm{a}}$ & $-0.33 \pm 0.01^{\mathrm{c}}$ & $2.21 \pm 0.09^{c}$ & $23.03 \pm 0.52^{c}$ & 89.51 \\
\hline & $\mathbf{P}$ & $94.80 \pm 0.08^{\mathrm{a}}$ & $-0.52 \pm 0.01^{\mathrm{de}}$ & $0.84 \pm 0.03^{\mathrm{f}}$ & $2.48 \pm 0.02^{\mathrm{de}}$ & \\
\hline \multirow[t]{2}{*}{ UV150 } & $\mathbf{R}$ & $94.46 \pm 0.08^{\mathrm{a}}$ & $-0.27 \pm 0.00^{\mathrm{b}}$ & $2.53 \pm 0.01^{\mathrm{b}}$ & $28.44 \pm 0.42^{\mathrm{b}}$ & 86.72 \\
\hline & $\mathbf{P}$ & $94.81 \pm 0.02^{\mathrm{a}}$ & $-0.49 \pm 0.00^{\mathrm{d}}$ & $0.88 \pm 0.01^{\mathrm{ef}}$ & $3.14 \pm 0.04^{\mathrm{d}}$ & \\
\hline \multirow[t]{2}{*}{ UC030 } & $\mathbf{R}$ & $94.58 \pm 0.07^{\mathrm{a}}$ & $-0.07 \pm 0.01^{\mathrm{a}}$ & $3.09 \pm 0.03^{\mathrm{a}}$ & $36.33 \pm 0.13^{\mathrm{a}}$ & 87.82 \\
\hline & $\mathbf{P}$ & $94.80 \pm 0.02^{\mathrm{a}}$ & $-0.52 \pm 0.01^{\mathrm{de}}$ & $1.00 \pm 0.01^{\mathrm{de}}$ & $2.88 \pm 0.01^{\mathrm{d}}$ & \\
\hline
\end{tabular}

${ }^{*} \mathrm{mg}$ of citric acid $/ 100 \mathrm{~g} ; \mathrm{R}=$ retentate; $\mathrm{P}=$ permeate; $\mathrm{SSR}=$ Suspended solids reduction. Different letters in the same column represent a significant difference at a level of confidence of $95 \%$.

\subsection{Analysis of color and turbidity}

Table 2 also shows the results of the color and turbidity of the feed, retentate, and permeate of the experiments conducted at the LU. The parameters $\left(\mathrm{L}^{*}, \mathrm{a}^{*}\right.$ and $\left.\mathrm{b}^{*}\right)$ measured during the color analysis showed a similar behavior for all of the membranes evaluated when comparing the feed, retentate and permeate. The parameter $\mathrm{L}^{*}$ corresponds to the luminosity that varies from 0 (black) to 100 (white). It was observed that for both the feed and the fractions obtained from all assays with MF and UF, the $\mathrm{L}^{*}$ value was close to 100 (between 94.44 and 94.88), i.e., lighter sample. In a study performed by Magalhães et al. (2005), brightness values close to 100 (between 96.1 and 100) were also found, exhibiting the same behavior. The values found in this study are slightly lower than those found by Magalhães et al. (2005), most likely due to the differences in the properties and composition of the raw material that varied according to growing conditions, stage of maturation, and variety among others. The coordinates $\mathrm{a}^{*}$ and $\mathrm{b}^{*}$ correspond to chromaticity; $\mathrm{a}^{*}$ varies from $+\mathrm{a}^{*}$ (red) to $-\mathrm{a}^{*}$ (green), and $\mathrm{b}^{*}$ from $+\mathrm{b}^{*}$ (yellow) to $-b^{*}$ (blue). It can be observed in Table 2 that all values of $\mathrm{a}^{\star}$ and $\mathrm{b}^{\star}$ are close to zero, indicating absence of color. In fact, when a visual comparison was made, it was observed that the characteristic coconut water color was maintained in the fractions obtained. No values of the parameters $a^{*}$ and $b^{*}$ have been found in studies on clarification of coconut water by membrane technology.

The haze values shown in Table 2 were obtained from the measurement of suspended solids; the higher the haze value, the more turbid is the solution. A significant difference $(p \leq 0.05)$ was observed between the feed and the permeate, i.e., there was a reduction in suspend solids in all experiments, ranging from 86.72 to $89.51 \%$. This was also confirmed by a visual comparison; the permeates obtained were transparent and clarified. The percentage decrease was calculated using a haze value of $100 \%$ for the feed's suspended solids.

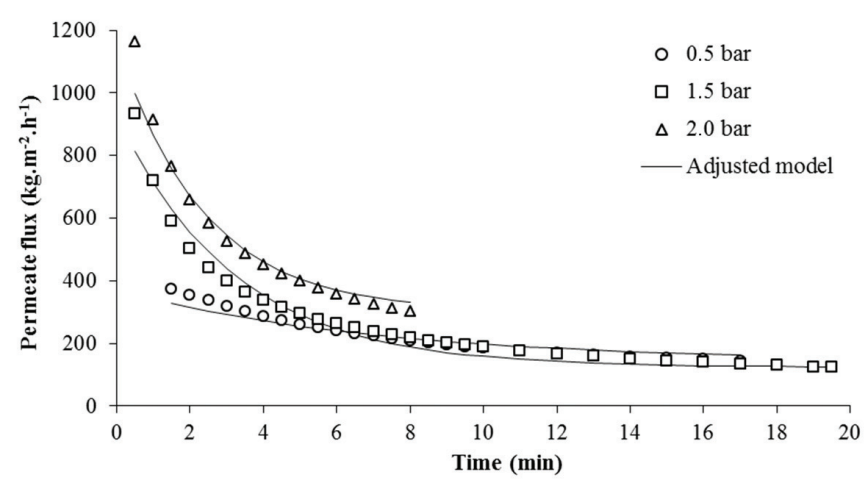

Figure 4. Permeate flux during ultrafiltration using UP150 membrane at LU.

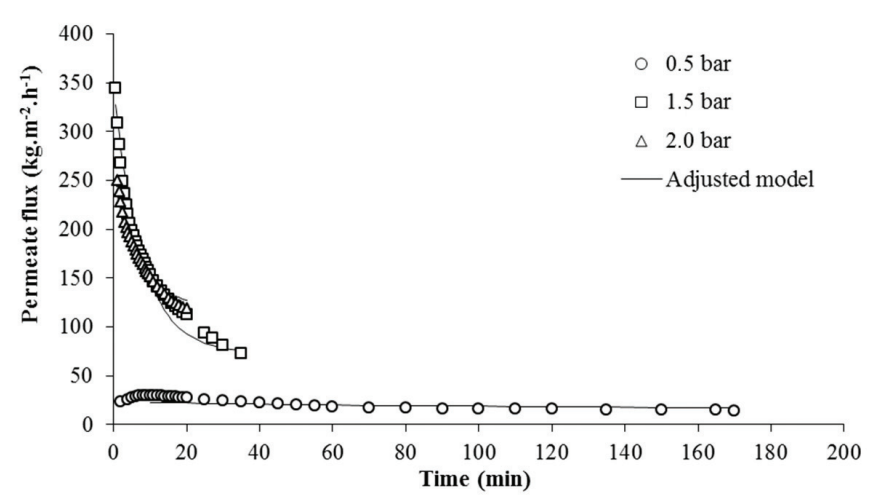

Figure 5. Permeate flux during ultrafiltration using UV150 membrane at LU.

\subsection{Permeate flux}

The permeate flux curves obtained for the experiments conducted at the LU are shown in Figures 4, 5, and 6, and those obtained for the PU are shown in Figure 7. The permeate flux when VRF reached 2 with the initial volume of $400 \mathrm{~mL}$ for $\mathrm{LU}$ and $20 \mathrm{~L}$ for PU, are shown in Table 3. 


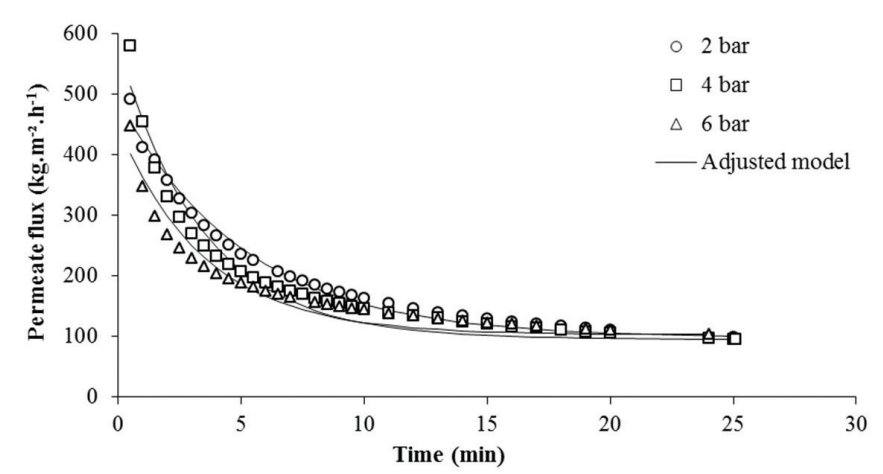

Figure 6. Permeate flux during ultrafiltration using UC030 membrane at LU.

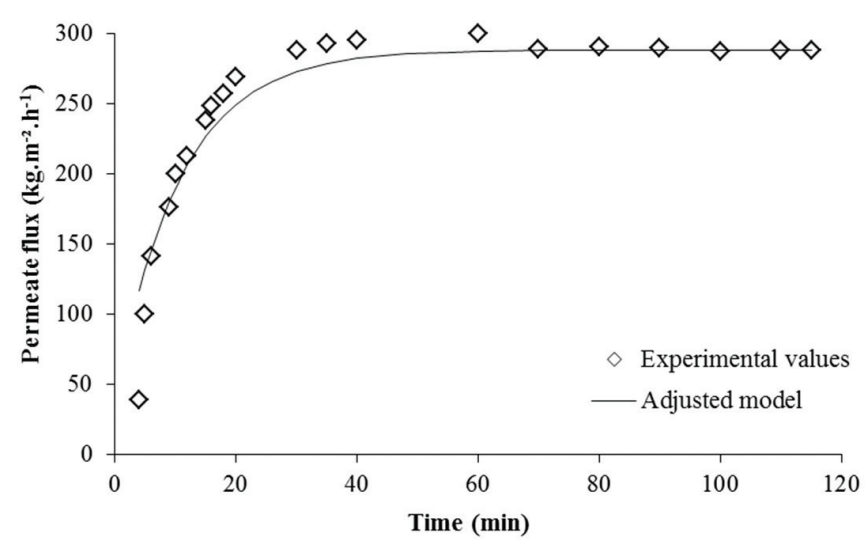

Figure 7. Permeate flux during ultrafiltration using UC030 membrane at PU.

Table 3. Permeate flux at VRF of $2\left(\mathrm{~J}_{\mathrm{F}}\right)$ for the $\mathrm{LU}$ and PU and parameters obtained from the surface renewal approach.

\begin{tabular}{|c|c|c|c|c|c|}
\hline Membrane & Pressure (bar) & $\mathrm{J}_{0}\left(\mathrm{~kg} \cdot \mathrm{m}^{-2} \cdot \mathrm{h}^{-1}\right)$ & $\mathrm{J}_{\mathrm{F}}\left(\mathrm{kg} \cdot \mathrm{m}^{-2} \cdot \mathrm{h}^{-1}\right)$ & $\lambda\left(\mathrm{h}^{-1}\right)$ & $\mathrm{R}^{2}$ \\
\hline \multirow{3}{*}{ UP150 } & 0.5 & 373.38 & $144.45^{\mathrm{a}}$ & 8.770 & 0.9219 \\
\hline & 1.5 & 933.13 & $123.54^{\mathrm{a}}$ & 18.926 & 0.9686 \\
\hline & 2.0 & 1162.97 & $301.16^{\mathrm{b}}$ & 25.375 & 0.9633 \\
\hline \multirow{3}{*}{ UV150 } & 0.5 & 23.17 & $14.62^{\mathrm{a}}$ & 0.422 & 0.3085 \\
\hline & 1.5 & 344.89 & $72.62^{\mathrm{b}}$ & 7.778 & 0.9562 \\
\hline & 2.0 & 249.76 & $118.64^{c}$ & 8.143 & 0.9746 \\
\hline \multirow{3}{*}{ UC030 } & 2.0 & 491.60 & $97.89^{\mathrm{a}}$ & 11.779 & 0.9883 \\
\hline & 4.0 & 578.46 & $95.18^{\mathrm{a}}$ & 17.363 & 0.9588 \\
\hline & 6.0 & 447.95 & $102.92^{\mathrm{a}}$ & 17.017 & 0.9414 \\
\hline UC030 & 2.0 & 38.88 & 288.37 & 5.593 & 0.9128 \\
\hline
\end{tabular}

Different letters for the same membrane represent a significant difference at a level of confidence of $95 \%$.

Since the variation of the results of duplicates was less than $10 \%$ for all experimental conditions evaluated, only their averages are shown.

It was observed that experiments with UP150 showed higher flux values than those of UV150 under the same operating pressures. This can occur due to the membrane characteristics such as material composition, morphology, molecular weight cutoff or pore size, and porosity. The molecular weight cutoff and morphology of these membranes are very similar (Table 1), according to the manufacturer information (MICRODYN-NADIR, 2007). The PVDF membrane has a more hydrophobic profile than the PES membrane. Therefore, it is expected that PES membranes result in higher flux values. Coconut water is considered an aqueous solution, and differences in its composition results in different flux values (CHERYAN, 1998). This was also observed by Riedl, Girard and Lencki (1998), who evaluated water flux in $0.2 \mu \mathrm{m}$ PVDF and PES membranes; different values of flux were found. It is likely that the pretreatment with water might have contributed to the higher flux values obtained with PES membranes due to the hydrophilic behavior of the PES membrane. However, in addition to the hydrophobic profile, it is also important to consider the distribution of pore size (porosity), which may vary (CHERYAN, 1998).
Figures 4 and 5 show the permeate flux curves of the UP150 and UV150 membranes, especially under pressures of $1.5 \mathrm{bar}$ and $2.0 \mathrm{bar}$; it can be seen a reduction in the flux as a function of operation time, resulting in an exponential curve typical of the UF process. There is a substantial reduction in the permeate flux at the beginning of the process due to the polarization layer, followed by stabilization or soft flux increase up to the end of the process. Such stabilization was not observed in the UV150 curves at pressures of 1.5 and 2.0 bar because the system reached VRF of 2 quicker when using these membranes. If higher VRF would have been used, these membranes would have eventually reached stabilization, as seen in the curves of the UP150 membrane at pressures of 0.5 and 1.5 bar at VRF of 2. As for the UC030 membrane, the behavior of the curves under all operating pressures showed typical behavior. Magalhães et al. (2005) also observed the typical behavior of the permeate flux in their MF and UF assays in a pilot unit at 2.0 bar with coconut water.

According to Table 3, for UP150 membrane, the pressure values of 0.5 and 1.5 did not result in a significant flux increase, while for the UV150 membrane, the permeate flux increased significantly with increasing operating pressure. For the UC030 membrane, increasing the operating pressure did not cause an 
increase in the permeate flux. This is due to the higher pressures that increase the concentration of molecules retained close to the membrane surface, a phenomenon called the polarization layer, which causes flux reduction. Thus, increasing the pressure above a certain value increases the solvent transport resistance, and therefore the flux remains virtually unchanged (HABERT; BORGES; NOBREGA, 2006).

By comparing the flux values at a $\mathrm{VRF}=2$ under pressure of $2.0 \mathrm{bar}$, it was observed that the larger the pore size, the higher the permeate flux, especially in relation to UP150 (301.2 $\left.\mathrm{kg} \cdot \mathrm{m}^{-2} \cdot \mathrm{h}^{-1}\right)$ when compared to UC030 $\left(97.9 \mathrm{~kg} \cdot \mathrm{m}^{-2} \cdot \mathrm{h}^{-1}\right)$. The molecules or particles that permeated through the pores of the membrane-feed interface are retained inside them, causing an irreversible phenomenon (clogging or blocking of the pores) reducing the porosity of the membrane irreversibly thus resulting in increased flux reduction.

The permeate flux of the UF process using the UC030 membrane in the PU at a VRF of 2 was $288 \mathrm{~kg} \cdot \mathrm{m}^{-2} \cdot \mathrm{h}^{-1}$, a very good flux value for industrial application. However, a flux decrease by $3.8 \%$ (299.83 to $288.37 \mathrm{~kg} \cdot \mathrm{m}^{-2} \cdot \mathrm{h}^{-1}$ ) was observed during the last hour of the process.

The permeate flux found using the PU was three times higher than that found using the LU due to the effect of tangential velocity. As shown in Figure 7, the flux behavior in the PU is different from that observed in the LU; there was a flux increase rather than a reduction at the beginning of the process with subsequent stabilization. Paradoxical flow is the increase in permeate flux as a function of time (GREEN; BELFORT, 1980). In this situation, the feed composition has various components, some of which have a wide range of particle size. Therefore, there is an initial deposition of smaller particles, which causes clogging of the membrane pores, and these particles are dragged by the permeate solution through the membrane. Subsequently, there is the prevalence of large particles in the polarized layer that ultimately facilitates the flux of permeate since such material deposited on the surface of the membrane are very porous due to the larger particles consequently increasing the flux (GREEN; BELFORT, 1980). Vaillant et al. (1999) observed the same behavior in a study on the tangential microfiltration of passion fruit juice after partial enzymatic liquefaction. The presence of paradoxal flux indicates that there is a change in the composition and configuration of the power-membrane interface. Thus, changes in the structure leads to changes in permeate flux resistance.

\subsection{Enzyme activity}

Table 4 shows the results of the enzyme activity of the feed and permeates obtained from the UF processes and the enzymatic retention percentage.

By comparing the enzymatic activity results of coconut water before and after the UF processes, it can be conclude that the process using UC030 was the most effective in retaining PPO and POD enzymes (it retained $100 \%$ of the enzymes). Smaller retention values ranging from 71 to $85 \%$ were obtained in UP150 and UV150 membranes. Rodrigues et al. (2003) evaluated the use of ultrafiltration for clarification and $\mathrm{PPO}$ removal in banana juice. For MWCO values of 10 and $30 \mathrm{kDa}$, the reduction in the enzyme activity were $97.5 \%$ and 96.2 , respectively. It is worth to mention that the feed material used by Rodrigues et al. (2003) has higher viscosity than that of the coconut water; therefore, different enzymatic retentions are expected. Cassano et al. (2008) evaluated the recovery of bioactive compounds in kiwifruit juice by ultrafiltration using a cellulose $30 \mathrm{kDa}$ membrane, and they found that $100 \%$ of PPO enzymes were retained in the retentate.

The PPO enzyme activity was 29.6 U.mL ${ }^{-1}$ and POD activity was $38.7 \mathrm{U} \cdot \mathrm{mL}^{-1}$ for in natura coconut water, and the activity of POD was more expressive than that of PPO. This effect was also observed by Campos et al. (1996), who found an enzyme activity value of $32.1 \mathrm{U} . \mathrm{mL}^{-1}$ for the PPO enzyme and 114.3 U.mL $\mathrm{m}^{-1}$ for the POD enzyme in coconut water in natura. The differences in the enzyme activities of in natura coconut water are probably due to differences in the composition of the raw material and the other factors previously mentioned. When the UC030 membrane was used, the permeate did not turn pink, resulting in a suitable product. On the other hand, when the other membranes were used, this color change was observed, resulting in a product unsuitable for human consumption.

\subsection{Adjusting the mathematical model}

The model based on surface renewal theory was applied to tamarind juice microfiltration (WATANABE; USHIKUBO; VIOTTO, 2006), pineapple juice ultrafiltration (BARROS et al., 2003), depectinized apple juice microfiltration (MONDOR; GIRARD; MORESOLI, 2000), and microfiltration processes to remove emulsions such as oil in water (KOLTUNIEWICZ; FIELD, 1996); therefore, this model was used in this study.

Table 3 shows that the model based on the surface renewal theory best represents the permeate flux behavior because the coefficients of determination $\left(R^{2}\right)$ values were higher than 0.91 , except for the UV150 membrane subjected to a pressure of 0.5

Table 4. Enzyme activities of the feed and permeates obtained from the UF process in the LU.

\begin{tabular}{|c|c|c|c|c|}
\hline & \multicolumn{2}{|c|}{$\mathrm{PPO}$} & \multicolumn{2}{|c|}{ POD } \\
\hline & Activity (U.mL $\left.{ }^{-1}\right)$ & Retention (\%) & Activity $\left(\mathrm{U} \cdot \mathrm{mL}^{-1}\right)$ & Retention (\%) \\
\hline Feed & $2.61 \pm 0.30$ & - & $7.22 \pm 0.23$ & - \\
\hline UP150 & $0.39 \pm 0.04$ & 85.06 & $1.56 \pm 0.22$ & 78.39 \\
\hline UV150 & $0.70 \pm 0.43$ & 73.18 & $2.07 \pm 0.03$ & 71.33 \\
\hline UC030 & 0 & 100 & 0 & 100 \\
\hline
\end{tabular}


bar. The model represents permeate flux as a function of time and VRF as a constant. Although the VRF changed during the UF processes in the present study, the model can still represent the experimental data.

The parameter " $\lambda$ " is associated with the permeate flux decline rate, i.e., the greater the decrease in flux in the first few minutes of the experiment, the higher the values of " $\lambda$ ".

It was observed that for most of the experiments in which there was a high initial permeate flux, the decline rate was also high $\left(\lambda>11.779 \mathrm{~h}^{-1}\right)$, indicating a sharp reduction in permeate flux at the beginning of the process.

Koltuniewicz and Field (1996) studied the application of microfiltration in the removal of oil in water emulsions using the model based on this theory to fit the experimental data obtained in both perpendicular and tangential filtration. This model best represented data obtained from tangential filtration. In the present study, it was found that the model better represented the data obtained from perpendicular filtration $\left(\mathrm{R}^{2}=0.94-0.98\right)$ in the LU compared with tangential filtration (PU) $\left(\mathrm{R}^{2}=0.91\right)$ for the UF of coconut water using the UC030 membrane.

Comparing the process of UF using the UC030 membrane in the LU and PU, the parameter " $\lambda$ " presented the lowest value for PU, indicating that the flux reached a constant value faster, in accordance with the curves shown in Figures 4 and 5.

\section{Conclusion}

The membranes used in this work have not been previously applied for the removal of enzymes from coconut water. From the results it was concluded that the UC030 membrane is the best to remove enzymes from coconut water. The permeate obtained from this membrane did not show any color changes since $100 \%$ of the enzymes were retained. The application of the UC030 membrane resulted in higher permeate flux. The permeate flux for UC030 in the PU was three time higher than that obtained in the LU at the same pressure, showing the positive effect of the tangential velocity.

The results of the physicochemical analysis indicate that ultrafiltration process does not alter the coconut water physicochemical properties. At the same time product quality is improved since there was a marked reduction in suspended solids, greater than $86 \%$. Furthermore, the model based on surface renewal theory represented the experimental data obtained from the LU and PU well, with $\mathrm{R}^{2}$ values higher than 0.91 .

Ultrafiltration represents a good choice to produce coconut water with high quality without requiring a thermal process for enzymatic inactivation. Also UC030 is a good membrane to be used to industrial process. The permeate flux obtained with UC030 is extremely attractive for industrial processes as it combines enzymatic retention with higher flux than those found in the literature.

\section{Acknowledgements}

The authors wish to acknowledge the financial support from CAPES (Coordination for the Improvement of Higher Education Personnel).

\section{References}

ALMANDOZ, C. et al. Corn syrup clarification by microfiltration with ceramic membranes. Journal of Membrane Science, v. 363, p. 87-95, 2010. http://dx.doi.org/10.1016/j.memsci.2010.07.017

ALPER, N.; ONSEKIZOGLU, P.; ACAR, J. Effects of various clarification treatments on phenolic compounds and organic acid compositions of pomegranate (Punica granatum L.) juice. Journal of Food Processing and Preservation, v. 5, p. 313-319, 2011. http:// dx.doi.org/10.1111/j.1745-4549.2009.00458.x

ASSOCIATION OF OFFICIAL ANALYTICAL CHEMISTS - AOAC. Official Methods of Analysis of the Association of Official Analytical Chemists. 16th ed. Gaithersburg: AOAC, 1997.

BARROS, S. T. D. et al. Study of fouling mechanism in pineapple juice clarification by ultrafiltration. Journal of Membrane Science, v. 215, p. 213-224, 2003. http://dx.doi.org/10.1016/S0376-7388(02)00615-4

BRUGGEN, B. V. et al. Influence of MF pretreatment on NF performance for aqueous solutions containing particles and organic foulant. Separation and Purification Technology, v. 36, p. 203-213, 2004. http://dx.doi.org/10.1016/S1383-5866(03)00216-8

CAMPOS, C. F. et al. Chemical composition, enzyme activity and effect of enzyme inactivation of flavor quality o green coconut water. Journal of Food Processing and Preservation, v. 20, p. 487-500, 1996. http://dx.doi.org/10.1111/j.1745-4549.1996.tb00761.x

CASSANO, A. et al. Recovery of bioactive compounds in kiwifruit juice by ultrafiltration. Innovative Food Science and Emerging Technologies, v. 9, p. 556-562, 2008. http://dx.doi.org/10.1016/j. ifset.2008.03.004

CHERYAN, M. Ultrafiltration and microfiltration handbook. Lacanster: Technomic Publishing Company, 1998.

CONSTENLA, D. T.; LOZANO, J. Predicting stationary permeate flux in the ultrafiltration of apple juice. LWT- Food Science and Technology, v. 38, p. 683-689, 1996.

GIRARD, B.; FUKUMOTO, L. R. Membrane Processing of Fruit Juices and Beverages: A Review. Critical Reviews in Biotechnology, v. 20, n. 2, p. 109-175, 2000. PMid:10890454. http://dx.doi. org/10.1080/07388550008984168

GREEN, G; BELFORT, G. Fouling of ultrafiltration membranes: lateral migration and particle trajetori model. Desalination, v. 35, p. 129 147, 1980. http://dx.doi.org/10.1016/S0011-9164(00)88607-5

HABERT, A. C.; BORGES, C. P.; NOBREGA, R. Membrane separation processes. Rio de Janeiro: E-papers, 2006.

HUNTERLAB. Cie $\mathbf{L}^{\star} \mathbf{a}^{\star} \mathbf{b}^{\star}$ Color Scale., 1996. (Applications Note, v. 8, n. 7).

JAYANTI, V. K. et al. Quantification of flux decline and design of ultrafiltration system for clarification of tender coconut. Journal of Food Processing and Preservation, v. 33, p. 128-143, 2010.

KIM, E. U.; LIU, Y.; EL-DIN, M. G. The effects of pretreatment on nanofiltration and reverse osmosis filtration for desalination of oil sands process-affected water. Separation and Purification Technology, v. 81, p. 418-428, 2011. http://dx.doi.org/10.1016/j. seppur.2011.08.016

KOLTUNIEWICZ, A. B.; FIELD, R. W. Process factors during removal of oil in-water emulsions with crossflow microfiltration. 
Desalination, v. 105, p. 79-89, 1996. http://dx.doi.org/10.1016/00119164(96)00061-6

MAGALHÃES, M. P. et al. Conservation of green coconut water by membrane filtration. Ciência e Tecnologia de Alimentos, v. 25, n. 1, p. 72-77, 2005. http://dx.doi.org/10.1590/S010120612005000100012

MICRODYN-NADIR. Products Brochure. Apr 2007.

MONDOR, M.; GIRARD, B.; MORESOLI, C. Modeling flux behavior for membrane filtration of apple juice. Food Research International, v. 33, p. 539-548, 2000. http://dx.doi.org/10.1016/ S0963-9969(00)00089-2

PRADES, A. et al. Coconut water uses, composition and properties: a review. Fruits, v. 67, n. 2, p. 87-107, 2012. http://dx.doi.org/10.1051/ fruits/2012002

REDDY, K. V.; DAS, M.; DAS, S. K. Filtration resistance in nonthermal sterilization of green coconut water. Journal of Food Engineering, v. 69, p. 381-385, 2005. http://dx.doi.org/10.1016/j. jfoodeng.2004.08.029
RIEDL, K.; GIRARD, B.; LENCKI, R. W. Influence of membrane structure on fouling layer morphology during apple juice clarification. Journal of Membrane Science, v. 139, p. 155-166, 1998. http://dx.doi.org/10.1016/S0376-7388(97)00239-1

RODRIGUES, S. L. C. et al. Parameters evaluation in banana juice ultrafiltration. Ciência e Tecnologia de Alimentos, v. 23, p. 98-101, 2003. http://dx.doi.org/10.1590/S0101-20612003000400018

VAILLANT, F. et al. Crossflow microfiltration of passion fruit juice after partial enzimatic liquefaction. Journal of Food Engineering, v. 42, p. 215-224, 1999. http://dx.doi.org/10.1016/S0260-8774(99)00124-7

WALTER, E. H. M. et al. Modelling the growth of Listeria monocytogenes in fresh green coconut (Cocos nucifera L.) water. Food Microbiology, v. 26, p. 653-657, 2009. PMid:19527842. http://dx.doi.org/10.1016/j. fm.2009.04.003

WATANABE, A. P.; USHIKUBO, F. Y.; VIOTTO, L. A. Evaluation of permeate flux in microfiltration of Tamarind (Tamarindus indica L.) juice using polypropylene membrane. Desalination, v. 200, p. 337338, 2006. http://dx.doi.org/10.1016/j.desal.2006.03.377 